\title{
Acute urinary retention due to sacral myeloradiculitis
}

\author{
JAN A L VANNESTE, * PETER P M KARTHAUS, $\dagger$ AND \\ GARETH DAVIES $\dagger$
}

From the Departments of Neurology,* Urology $\dagger$ and Radiology, ${ }_{\ddagger}$ Sint Lucas Ziekenhuis, Amsterdam, The Netherlands

SUMMARY Three cases of acute urinary retention without local urological causes are described. A diagnosis of sacral myeloradiculitis of viral origin appeared more likely than a first episode of multiple sclerosis. The literature is reviewed and a protocol for the investigation of such patients is suggested.

\section{Case reports}

Case 1 A 20-year-old female student noticed extreme fatigue, malaise and generalised skin hyperaesthesia for two days. On the third day these symptoms disappeared, but she complained of dysuria for three days followed by acute retention. Catheterisation in the casualty department revealed a residual volume of $1500 \mathrm{ml}$. Clinical and neurological examination was normal. As she was currently at loggerheads with her parents, a psychogenic cause was suggested and she was advised "to jump frequently downstairs in order to activate the bladder". This therapeutic suggestion failed and she was readmitted to hospital with retention $(1400 \mathrm{ml})$. The external urogenital tract was normal, cystoscopy showed no infravesical obstruction, and a voiding cystogram showed only residual urine. Blood and urine analysis were normal. A detailed neurological examination showed no abnormalities. In view of the non specific symptoms suggesting a viral illness, a lumbar puncture was performed which showed a colourless liquor under normal pressure. Laboratory findings are shown in the table. The retention resolved rapidly, and the patient was discharged symptom free on the fifth day. She had remained well for three years. No causative viral agent could be detected.

Case 2 A 31-year-old female school teacher presented with a two day history of malaise and myalgia. She had noticed frequency and dysuria resulting in acute retention. On admission, the external urogenital tract appeared normal. The bladder was

Address for reprint requests: Dr JAL Vanneste, Sint Lucas Ziekenhuis, Jan Tooropstraat 164, 1061 AE Amsterdam, The Netherlands.

Accepted 30 July 1980 large with a residual urine of $1300 \mathrm{ml}$. Apart from an inconstant sacral hypalgesia (S1-3), neurological examination was normal. Cystoscopy and intravenous urography revealed no abnormalities. At lumbar puncture a pleocytosis was present (see table). Viral cultures were negative but the ECHO 9 complement fixation tests rose from $1 / 8$ (day 2) to $1 / 128$ (day 17), suggesting a sacral myeloradiculitis of viral origin. The retention resolved over three days, and the patient has remained well for 18 months.

Case 3 A 21-year-old housewife complained of dysuria and was treated by her family doctor with sulphonamides. Acute retention developed one week later and she was admitted to hospital. The external urogenital tract was normal. The bladder was enlarged with a residual urine of $1350 \mathrm{ml}$. Neurological examination was normal apart from a possible decrease in anal sphincter tone. Blood and urine analysis were normal. Cystoscopy and voiding cystourethrogram showed no abnormality apart from residual urine. At lumbar puncture a pleocytosis was again present (see table). Viral studies were negative. The retention resolved rapidly and the patient has been well for 18 months.

\section{Discussion}

Acute urinary retention as an isolated sign is rarely of neurological origin: multiple sclerosis, medullary compression or a disc protrusion are well recognised causes. Minor complaints such as transient paraesthesiae can be overlooked leading to extensive urodynamic investigations ${ }^{1-3}$ in search of a local cause. If these investigations are negative, a psychogenic aetiology is often considered $^{2-6}$ particularly in young women who 
Table CSF findings in three reported cuses

\begin{tabular}{|c|c|c|c|c|c|c|}
\hline \multirow{2}{*}{$\begin{array}{l}\text { Patient } \\
1\end{array}$} & \multirow{2}{*}{$\begin{array}{l}\text { Protein } \\
0 \cdot 22 \mathrm{~g} / 1\end{array}$} & \multicolumn{2}{|c|}{ White blood cells $/ \mathrm{mm}^{3}$} & \multirow{2}{*}{$\begin{array}{l}\text { Glucose } \\
3 \cdot 2 \\
\mathrm{mmol} / \mathrm{l}\end{array}$} & \multirow{2}{*}{$\begin{array}{l}\text { Globulins and } \\
\text { IgG's } \\
\text { nil }\end{array}$} & \multirow{2}{*}{$\begin{array}{l}\begin{array}{l}V D R L T P I \\
\text { tests }\end{array} \\
\text { neg }\end{array}$} \\
\hline & & $\begin{array}{r}24 \\
8\end{array}$ & $\begin{array}{l}\text { lymphocytes } \\
\text { polymorphonuclears }\end{array}$ & & & \\
\hline 2 & $0.40 \mathrm{~g} / 1$ & $\begin{array}{l}48 \\
20\end{array}$ & $\begin{array}{l}\text { lymphocytes } \\
\text { polymorphonuclears }\end{array}$ & $\begin{array}{l}3 \cdot 5 \\
\mathrm{mmol} / 1\end{array}$ & nil & neg \\
\hline $\begin{array}{l}3 \mathrm{a} \\
\text { (day 1) }\end{array}$ & $0 \cdot 70 \mathrm{~g} / 1$ & $\begin{array}{r}141 \\
20\end{array}$ & $\begin{array}{l}\text { lymphocytes } \\
\text { polymorphonuclears }\end{array}$ & $\begin{array}{l}3 \\
\mathrm{mmol} / 1\end{array}$ & nil & neg \\
\hline $\begin{array}{l}3 \mathrm{~b} \\
\text { (day :) }\end{array}$ & $0 \cdot 50 \mathrm{~g} / 1$ & $\begin{array}{r}33 \\
1\end{array}$ & $\begin{array}{l}\text { lymphocytes } \\
\text { polymorphonuclears }\end{array}$ & $\begin{array}{l}3 \cdot 2 \\
\mathrm{mmol} /\end{array}$ & nil & neg \\
\hline
\end{tabular}

appear unconcerned with their illness. ${ }^{45}$ In these cases exclusion of a neurological cause is often made on clinical examination alone. ${ }^{12} 4$

All our patients were young women who presented with a viral-like illness culminating in acute retention without a local cause. Neurological signs were minimal but the CSF was abnormal in all cases. A definitive viral agent (ECHO 9) was identified in one case. A first episode of multiple sclerosis cannot be excluded in any of these cases, but with normal CSF immunoglobulin analysis, a symptom free followup period of several years, and the absence of other neurological signs, a diagnosis of viral sacral myeloradiculitis seems more likely.

Sacral myeloradiculitis of viral origin is a rare but important differential diagnosis. Oates and Greenhouse $^{7}$ found 17 patients presenting with acute retention in 486 patients with anogenital herpes simplex infections. Neurological signs were frequently confined to slight sacral hyperaesthesia: the CSF was examined in three of these 17 patients and showed a pleocytosis: the authors conclude that herpetic sacral myeloradiculitis is the commonest cause of acute retention in the young sexually active population. Caplan et $a l^{8}$ described 11 young adults with genital herpes and signs of lumbosacral myeloradiculopathy. They stressed the paucity of neurological signs and symptoms except for bladder retention. Lumbar puncture was performed in three cases, all exhibiting pleocytosis. This syndrome of genital vesicular skin lesions, sacral paraesthesiae and bladder dysfunction regressed without treatment. Samarasinghe et al ${ }^{9}$ found 11 patients with acute retention in 236 homosexual men with herpetic proctitis. Lumbosacral radiculopathy was suggested. The CSF was not examined. Similar cases have been reported in herpes simplex ${ }^{10}$ and herpes zoster infections. ${ }^{11-14}$ Other authors have suggested that sacral myeloradiculitis can follow infection with neurotropic viruses of undetermined origin: Mumenthaler ${ }^{15}$ described the combination of acute retention and
CSF pleocytosis as the Elsberg syndrome, following Elsberg's original description in 1931. Lymphocytic meningoradiculitis-the Bannwarth's syndrome-may present as CSF lymphocytosis with minimal clinical signs. ${ }^{16}$ A viral aetiology is also suggested (arbo, picorna, Coxsackie and ECHO virus). In both lymphocytic meningoradiculitis and herpetic myeloradiculopathy, however, radicular pain and dysaesthesia are usually prominent presenting symptoms and signs.

None of our patients had signs of urogenital infection and neurological symptoms were minimal or even absent. They all presented with acute retention, poor bladder contractions, a large capacity and high residual volume: these findings suggested a lesion at the sacral cord level or in the sacral roots. Standard works do not describe neurogenic urinary retention as complicating ECHO virus infections ${ }^{17-20}$ and case reports with this picture could not be found.

In conclusion, in young patients presenting with acute retention without a local cause, clinical examination may not be enough to exclude a sacral myeloradiculitis of viral origin. Nonspecific symptoms such as fatigue, myalgia and malaise may suggest this diagnosis. Lumbar puncture-when positive-may preclude further urological investigations. In our cases, although a first episode of multiple sclerosis cannot be excluded, a viral myeloradiculitis has to be considered as the most probable underlying cause.

The secretarial assistance of Wilma Stoke is gratefully acknowledged.

\section{References}

1 Blaivas JG, Labib KB. Acute urinary retention in women. Urology 1977; 10:383-9.

2 Barrett DM. Evaluation of psychogenic urinary retention. J Urol 1978; 120:191-2.

3 Emmett JL, Hutchins SPR, McDonald JR. The treatment of urinary retention in women by transurethral resection. J Urol 1950; 63:1031-42. 
4 Larson SW, Swenson WM, Utz DC et al. Psychogenic urinary retention in women. JAMA 1963; 184:697-700.

5 Margolis GJ. A review of the literature on psychogenic urinary retention. J Urol 1965; 94: 257-8.

6 Rowan EL. Psychophysiologic disorders of micturition. J Amer Coll Health Ass 1975; 23:251-6.

7 Oates JK, Greenhouse PRDH. Retention of urine in anogenital herpetic infection. Lancet 1978; 1:691-2.

8 Caplan LR, Kleeman FJ, Berg S. Urinary retention probably secondary to herpes genitalis. $N$ Engl J Med 1977; 297:920-1.

9 Samarasinghe PL, Oates JK, MacLennan IPB. Herpetic proctitis and sacral radiculomyelopathy. Br Med J 1979; 297:365-6.

10 Baringer JR. Herpes simplex meningitis and radiculitis. In: Vinken $\mathrm{PJ}$, Bruyn $\mathrm{GW}$, eds. Handbook of Clinical Neurology. Amsterdam: NorthHolland Publishing Company, 1978: 34, 145-60.

11 Richmond W. The genitourinary manifestations of herpes zoster: three case reports and a review of the literature. Brit J Urol 1974; 46:193-200.

12 Jellinek EH, Tullock WS. Herpes zoster with dysfunction of bladder and anus. Lancet 1976; 2:1219-22.

13 McKendall RR, Klawans HL. Nervous complications of varicella-zoster virus. In: Vinken PJ,
Bruyn GW, eds. Handbook of Clinical Neurology. Amsterdam: North Holland Publishing Company, 1978: 34, 161-83.

14 Gayral L. Meningo-radiculite de la queue de cheval et herpes. Encephale 1953; 42:274-82.

15 Mumenthaler M. Das Elsberg-Syndrom. In: Mumenthaler $\mathbf{M}$, Schliack $\mathbf{H}$, eds. Läsionen Peripherer Nerven. 3e Auflage. Stuttgart: Georg Thieme Verlag, 1977: 155.

16 Meyer-Rienecker HJ, Hitzschke B. Barnwarth's syndrome (lymphocytic meningoradiculitis). In: Vinken PJ, Bruyn GW, eds. Handbook of Clinical Neurology. Amsterdam: North Holland Publishing Company, 1978: 34, 571-86.

17 Weiner LP. Enterovirus infections of the nervous system other than poliovirus: Echoviruses. In: Vinken PJ, Bruyn GW, eds. Handbook of Clinical Neurology. Amsterdam: North Holland Publishing Company, 1978: 34, 133-43.

18 Contamin F, Sabouraud O. Les virus Echo. In: Neurologie, vol 2. Paris: Flammarion, 1970: 882.

19 Brain Lord, Walton JN. The Echo viruses. In: Diseases of the nervous system. Eighth edition. Oxford: Oxford University Press, 1977: 517.

20 Nieberg KC, Blunberg JM. Viral encephalitides. In: Minckler J, ed. Pathology of the nervous system, vol III. New York: McGraw-Hill Book Co, 1972: 2269-75. 